\title{
The Effect of Financial Literacy on Personal Investment Decisions amongst Medical Practitioners in Sri Lanka
}

\author{
S. H. M. L. Walakumbura
}

ABSTRACT

Financial literacy is very essential for any individual in order to efficient and effective decisions regarding their personal investments. Based on that scenario, this study examines the impact of financial literacy on personal investment decisions amongst medical practitioners in Sri Lanka. Personal investment decision has been considered as the dependent variable while financial knowledge, financial skills and financial attitude has been considered as the proxies for the independent variable. Deductive approach has been employed using primary data which is obtained from 205 respondents throughout the country. Descriptive and inferential statistics such as multiple linear regression have been used for the analysis purpose. The results suggested that there is a significant impact between the financial knowledge and financial skills on investment decision while the financial attitude does not have a significant impact on the investment decision. The empirical findings of this study are helpful for any individual who is willing to take effective investment decisions, academics, policy makers and all other related interested parties.

Keywords: Financial literacy, Investment decision, Financial attitude, Financial skill.

\section{INTRODUCTION}

Financial literacy enhances individual's knowledge and understanding regarding the financial matters and it helps their decision making process in relevant to personal finance. With the emergence of many new financial products worldwide, individuals may come across in issues relevant to their savings, borrowings, investment, and retirement planning. For the individuals who are not financially literate. It is very difficult to take effective decisions regarding the financial products by comparing the risk and the return. Hence for any individual a certain amount of financial literacy is needed.

The author defines financial literacy as the capability of exercising right judgment when making decisions relating to financial matters [1]. At times when individuals do not possess adequate financial knowledge, they tend to incur more and will go for more debts rather than having saving plans. Financial literacy should be given in early stages of life as its consequences are long-lasting throughout the life. Reading, writing, and numerical skills build up the foundation of the financial literacy. When individuals reach to adult hood, they have to face major milestones in life as securing a job, purchasing or building a home or starting a new savings plan. The financial choices which may take in early stage of life will lead to either life of worry or life of comfort at the end. Hence financial literacy is essential, and it plays a vital role [1].

Individuals may have different levels of savings based on the risk uptake and their risk appetites. Financial capability of an individual, health, preferences, individual perceptions, public policies, and available market opportunities plays a major role when defining the difference between actual and
Submitted : June 23, 2021

Published : July 15, 2021

ISSN: 2507-1076

DOI: $10.24018 /$ ejbmr.2021.6.4.952

S. H. M. L. Walakumbura*

Sabaragamuwa University of Sri Lanka, Sri Lanka.

(email: lakminiwalakumbura2@gmail.com)

*Corresponding Author

adequate level of savings. Most of the households are in a situation where they cannot perform simple calculations due to lack of basic knowledge and most of their savings' methods are based on try and error method [2]. Financial literacy seems to be an adequate area where every individual needs to cater towards.

Without taking decisions irrationally, financially educated investors will do a fundamental or technical analysis before they take a decision. As well high literate individuals have a good position to protect them in financial frauds [11]. Furthermore, financially educated individuals lead to more savings, and it will in turn lead to a higher economic development. It is clearly shown that countries with higher rates of savings have a faster economic growth than other developing countries. In order to do an effective investment, People should have through knowledge in financial matters.

As well wide gap has been found in informational endowment in development nations and investors within these nations are having very little information sources to enable them to make decisions on their investments [8]. Hence it can be noticed that there is a gap regards this particular context both in developing and developed nations. As per that this study sought to establish the impact of financial literacy on investment decision making.

\section{A. Problem Statement}

The problem statement of this research paper can be demarcated as,

"What is the effect of financial literacy on personal investment decisions of medical practitioners of Sri Lanka?"

\section{B. Significance of the Study}

Individual investors and the managers or trustees who are involved in making investment decisions on behalf of the 
organizations will get an opportunity to enhance their knowledge about the factors in financial literacy which influencing their investment decisions. As well the findings of the study will help to enrich the existing literature and the study can be used as a reference material for researchers in their future findings in the area of financial literacy.

\section{LITERATURE REVIEW}

\section{A. Financial Literacy}

Financial literacy was developed by the "Organization for Economic Co-Operation and Development" which states that: "Financial literacy is the combination of consumers, investors understanding of financial products and concepts and their ability and confidence to appreciate financial risks and opportunities, to make informed choices, to know where to go for help, and to take other effective actions to improve their financial well-being." [10].

In addition, researchers acknowledges that financial literacy means more than just understanding how things work but also includes making informed choices. Moreover, financial literacy also defined as the process which "individuals use a combination of skills, resources, and contextual knowledge to process information and make decisions with knowledge of the financial consequences of that decision" [3].

In this meaning, financial literacy relates to the awareness of financial concepts there leading in the capacity to make knowledgeable assertive and convenient money-related options. All researchers agree that the ability to use the financial knowledge, make informed judgments, understand key financial concepts in order to manage the financial resources and making the effective decision whether through short-term or long-term investments, taking into consideration the changes in the economic world and its situations. However, the concept of financial literacy depends on the adjusted approach or is a component of the wide ranging consumer awareness and protection process [8].

\section{B. Financial Literacy and Investment Decisions}

Studies on personal finance have examined the significant impact of financial literacy on economic development, for instance through the effects of financial illiteracy on financial decision making. In Malaysia, authors provide evidence on the effect of financial literacy on financial distress among Malaysian youths. Their study shows that the levels of respondents' financial distress and financial literacy were moderate with a positive but weak relationship between these two variables. The results thus point to the fact that the relevant agencies and organizations should invest in human resources with respect to personal financial management as such knowledge investment would help raise the level of financial literacy among individuals and achieve the nations own objectives of high productivity [5]. Studies for other lesser developed countries, such as India and Indonesia demonstrated by the researcher who examines financial literacy level, its determinants, and the effect on the demand for financial services. They observe a strong relationship between financial literacy and financial behaviour and that financial literacy is an important correlate of household financial behaviour and household wellbeing [3].

\section{METHODOLOGY AND EXPERIMENTAL DESIGN}

\section{A. Data}

The researcher has used the primary data for this study. The essential data has been gathered from questionnaires. A structured questionnaire has been used to collect data from medical practitioners in a purposive sampling basis all across the country.

The questionnaire is composed of two parts. The first part concerned with collecting data about the demographic characteristics of respondents, while the second part donated to collect about the financial knowledge, financial skills and financial attitude. Five Likert scale has been used to measure the trends of sample for the different items.

\section{B. Data Analysis and Presentation}

The primary data of the study would be compiled, sorted, edited, classified, coded, and analyzed using the computerized data package known as SPSS. Researcher has been used descriptive statistics and inferential statistics like binary logistic regression to check the effect of financial knowledge, financial skills and financial attitude on personal investment decision. Further researcher has used Cronbach's Alfa value, Skewness and Kurtosis values and Variance Inflation Factor to test reliability, normality and multicollinearity of the data set respectively.

\section{Descriptive Statistics}

Descriptive statistics use to summarize the information of the sample and it does not help to generalize the information of the sample to the population unlike in the inferential statistics.

\section{Multiple Regression Analysis}

Multiple regression analysis is an inferential statistical tool which used to predict the value of the dependent variable based on two or more independent variables. In this analysis, the dependent variable is modeled as a function of several independent variables with their corresponding coefficients along with the constant term.

\section{RESUlTS}

\section{A. Demographic Information of the Respondents}

Table I shows the demographic information of the sample and this particular sample consists with medical practitioners all around the country.

\section{B. Descriptive Statistics}

As per the Table II, the maximum and the minimum value for the financial knowledge is 4.83 and 1 respectively. Its mean value is 2.57 and it can change either negatively or positively by 0.65 . The maximum and the minimum value for the financial skills is 5 and 1.33 respectively. Its mean value is 3.22 and it can change either negatively or positively by 0.67 . The maximum and the minimum value for the financial attitude is 5 and 1.67 , respectively. Its mean value is 3.26 and it can change either negatively or 
positively by 0.55 . The maximum and the minimum value for the investment decision is 4.57 and 1.00, respectively. Its mean value is 3.09 and it can change either negatively or positively by 0.64 .

TABLE I: DEMOGRAPHIC INFORMATION

\begin{tabular}{clcc}
\multicolumn{4}{c}{ TABLE I: DEMOGRAPHIC INFORMATION } \\
\hline \multirow{5}{*}{ Gender } & Male & Frequency & Percentage \\
& Female & 128 & 62.44 \\
& Below 30 years & 47 & 37.56 \\
& 30-35 years & 106 & 23.41 \\
& 36-40 years & 25 & 51.71 \\
& 41-45 years & 16 & 12.2 \\
Education & 46 years and above & 10 & 7.8 \\
& Bachelor's degree & 183 & 4.88 \\
& Post graduate & 3 & 89.27 \\
& diploma & & 1.46 \\
& Post graduate & 8 & \\
& degree & 11 & 3.9 \\
& PHD & 79 & 5.37 \\
Profession & Dental Surgeon & 114 & 38.54 \\
& Medical officer & 12 & 55.61 \\
& Consultants & & 5.85 \\
\hline \multirow{5}{*}{ Source: Survey } & &
\end{tabular}

Source: Survey data.

TABLE II: DESCRIPTIVE STATISTICS

\begin{tabular}{lllll}
\multicolumn{1}{c}{ Variable } & Minimum & Maximum & Mean & $\begin{array}{c}\text { Std. } \\
\text { Deviation }\end{array}$ \\
\hline $\begin{array}{l}\text { Financial } \\
\text { knowledge }\end{array}$ & 1 & 4.83 & 2.57 & 0.65 \\
$\begin{array}{l}\text { Financial skills } \\
\text { Financial }\end{array}$ & 1.33 & 5 & 3.22 & 0.67 \\
$\begin{array}{l}\text { attitude } \\
\begin{array}{l}\text { Investment } \\
\text { decision }\end{array}\end{array}$ & 1.67 & 5 & 3.26 & 0.55 \\
\hline
\end{tabular}

Source: Survey data.

\section{Regression Analysis}

\section{1) Cronbach's Alfa}

Cronbach's Alfa value is calculated to test the internal consistency reliability of the instrument. For this study, result of reliability analysis as follows.

\begin{tabular}{cc} 
TABLE III: TEST OF RELIABILITY \\
\hline Variable & Cronbach's Alpha \\
\hline Financial knowledge & 0.907 \\
Financial skills & 0.786 \\
Financial attitude & 0.77 \\
Investment decision & 0.799 \\
\hline
\end{tabular}

Source: Survey data.

Table III shows the Cronbach's Alpha value is higher than 0.7 , hence questionnaire can be considered as reliable.

2) Normality test

Skewness and Kurtosis are used to measure the normality. To have the normality in the data set, values of Skewness and Kurtosis should be near to zero. Skewness and Kurtosis test output for this study is as follows.

\begin{tabular}{llll}
\multicolumn{3}{c}{ TABLE IV: TEST OF NORMALITY } \\
\cline { 2 - 4 } Variable & Skewness & \multicolumn{1}{c}{ Kurtosis } \\
\hline Financial knowledge & 0.217 & 0.335 \\
Financial skills & -0.162 & -0.206 \\
Financial attitude & -0.089 & 0.626 \\
Investment decision & -0.267 & 0.334 \\
\hline
\end{tabular}

Source: Survey data.
Skewness and Kurtosis values imply that the data set has normally distributed because the values are around zero as per the Table IV.

\section{3) Multicollinearity}

\begin{tabular}{cc} 
& \multicolumn{2}{c}{ TABLE V: TEST OF MULTICOLLINEARITY } \\
\cline { 2 - 3 } Variable & VIF \\
\hline Financial knowledge & 1.136 \\
Financial skills & 1.541 \\
Financial attitude & 1.444 \\
Source: Survey data.
\end{tabular}

All variables VIF factors are less than 5.it provides enough evidence to express that there is no multicollinearity situation in the data set.

4) Significance of the model

\begin{tabular}{ccc}
\multicolumn{2}{c}{ TABLE VI: REGRESSION OUTPUT } \\
\hline Predictor & Coefficient & P Value \\
\hline Constant & 0.433 & 0.045 \\
Financial knowledge (FK) & 0.461 & 0 \\
Financial skills (FS) & 0.357 & 0 \\
Financial attitude (FA) & 0.002 & 0.965 \\
\hline
\end{tabular}

Source: Survey data.

When consider about $\mathrm{P}$ value, it implies of the significant level. $\mathrm{P}$ value of the financial knowledge and financial skills is 0.000 . It provides enough evidence to prove that there is significant impact between financial knowledge and financial skills on personal investment decisions. But $\mathrm{P}$ value for the financial attitude is 0.965 and it is above the significant value. Therefore, financial attitude did not significantly impact personal investment decision.

5) Fitted model

As per the above analysis, financial attitude has been removed from the final model because of the insignificancy and the below Model has been selected as the final fitted regression model.

The estimated regression equation is:

$$
\gamma=\beta o+\beta 1 \times 1+\beta 2 \times 2+\varepsilon
$$

$Y_{i}=$ Investment decisions;

$\beta_{0}, \beta_{1} \beta_{2}=$ Estimated Regression Coefficients;

$\mathrm{x}_{1}=$ Financial knowledge;

$\mathrm{x}_{2}=$ Financial skills;

$\varepsilon_{\mathrm{i}}=$ Random Error Term.

According to the output of regression analysis of this study, the researcher has formulated the final fitted regression model as follows:

$$
\text { Investment decisions }=0.433+0.461 \mathrm{x}_{1}+0.357 \mathrm{x}_{2}+\varepsilon
$$

$\beta_{0}$ describes that it is expected to influence investment decisions of 0.433 , when there is not any impact of independent variables while $\beta_{1}$ describes that efficiency in investment decisions can be increased by 0.461 if financial knowledge is increased by 1 unit. $B_{2}$ describes that efficiency in investment decisions can be increased by 0.357 if financial skills are increased by 1 unit.

6) Hypotheses Testing

Based on the above analysis, final outcome can be demarcated as follows. 
TABLE VII: HYPOTHESIS TESTING

\begin{tabular}{lc}
\multicolumn{2}{c}{ TABLE VII: HYPOTHESIS TESTING } \\
\hline \multicolumn{1}{c}{ Hypotheses } & Result \\
\hline H1 0: There is no significant impact of financial & Rejected \\
knowledge on personal investment decision & \\
H2 0: There is no significant impact of financial & Rejected \\
skills on personal investment decision & \\
H3 0: There is no significant impact of financial & Accepted \\
attitude on personal investment decision & \\
\hline Source: Survey data.
\end{tabular}

Source: Survey data.
[9] Muizzuddin, et al., 2017. Financial Literacy; Strategies and Concepts in Understanding the Financial Planning with Self-Efficacy Theory and Goal Setting Theory of Motivation Approach. International Journal of Economics and Financial Issues, pp. 182-188.

[10] OECD. (2008),Recommendations on good practices for financial education relating to private pensions, OECD publishing.

[11] R. Volpe, J Kotel, and H Chen, (2002), "A survey of investment literacy among online investors", Financial Counseling and Planning, Vol. 13 No. 1, pp. 1-13.

[12] Worthington, Andrew. (2006). Predicting Financial Literacy in Australia. Financial Services Review. 15.

\section{DISCUSSION AND CONCLUSION}

The impact of financial literacy plays a vital role when taking personal investment decisions efficiently and effectively. In this paper, researcher tried to investigate the impact of financial literacy on personal investment decisions amongst medical practitioners in Sri Lanka based on the primary data collected from 205 respondents.

Descriptive statistics and inferential statistics such as multiple regression have been employed to analyze the data. The results of the regression analysis imply that there is no any impact of financial attitude to the investment decision and only financial knowledge and financial skills are having a significant impact towards the investment decision.

Based on existing literature, the researcher developed the conceptual framework considering only financial knowledge, financial skills and financial attitude to investigate the impact of these factors on personal investment decision with reference to the Sri Lankan context. In further developments researchers have ability to find other factors that are influencing on investment decisions other than above three factors. The findings of this study will help investors, academics, policy makers and all the interested parties. As well policy makers can apply financial literacy aspects in curriculum revising in the education system in each and every stream hence it directly links to anyone living standard and the economy of the country.

\section{REFERENCES}

[1] C. Alexander, J. Marple, C. Jones, (2011), Special report TD Economics.

[2] D. Bernheim, (1995). Do households appreciate their financial vulnerabilities? An analysis of actions, perceptions, and public policy, in: Tax Policy and Economic Growth, American Council for Capital Formation, Washington, DC, 1-30.

[3] S. Cole, T. Sampson, and B. Zia, (2009), "Financial literacy, financial decisions, and the demand for financial services: evidence from India and Indonesia”, Harvard Business School Working Paper No. 09-117, pp. 1-24.

[4] Edirisinghe, Keerthipala \& Ama, (2017). Financial Literacy and Financial Behavior of Management Undergraduates of Sri Lanka Australia, Sabaragamuwa University of Sri Lanka.

[5] I. Faoziah, D.K Sarojani, A Norfiza (2013) Relationship between financial literacy and financial distress among youths in Malaysia An empirical study. Geografia-Malaysian Journal of Society and Space 9(4), $106-117$.

[6] K Fariba, Z Hajiha, S. Nabiyuni, \& M.A Khalili (2013). Effect of the Social accountability on Incoming and Earnings Response constant. Progress in Management Sciences, 1(1), 8-14.

[7] C. J Kelleher, L. D Cardozo, V. Khullar, \& S. Salvatore, (1997). new questionnaire to assess the quality of life of urinary incontinent women. BJOG. An International Journal of Obstetrics \& Gynaecology, 104(12), 1374-1379.

[8] W. G Kibuthu, (2005), Capital Markets in Emerging Economies.A Case of the Nairobi Stock Exchange. Unpublished MA Thesis. The Fletcher School, Tufts University 